\title{
DIFFERENCES IN SOCIAL REPRESENTATIONS ABOUT SCHOOL OF PUPILS WITH AND WITHOUT BEHAVIOR DISORDERS Oana DĂU-GAȘPAR*
}

\section{Abstract:}

The research is based on the premise that social representations are both a form of acknowledging the reality and clues on how one is interpreting that reality. In this respect, we presume the existence of certain differences between the social representation about school of pupils without any behavior disorders and those with this kind of disorders. Such differences are proved by the current study. The results show that pupils with behavior disorders are likely to associate with school rather negative elements, such as boredom, fatigue, tests, while the social representation of the pupils without behavior disorders is mostly centered on positive elements, such as play, beauty or cleanliness. These findings have implications upon the differentiated psychopedagogical strategy used to work with children with behavior disorders in comparison with those without such disorders.

Keywords: social representation, school social environment, behavior disorders, primary school pupils.

\section{Introduction}

Man is born and develops in society; he is a "zoon politikon" as Aristotle called him. The child, from the earliest months of life, needs the social element, to which he gradually learns to relate. In the first stage of the ontogenetic development, the baby uses his own mother, who gives him food and care, as a social bench-mark. After the first year of life the child's social circle widens, containing also the father. From there after, with age, the social circle will include an increasingly variety of people and social groups - the members of the extended family, school, circle of friends, etc.

Dealing with different social systems determines the individual to structure elaborated ways of knowing the surrounding reality, among these being included the social representations. Serge Moscovici (1997) considers the social representations a particular way to learn and to transmit what is known, because they occupy a particular place between the concept - which serves at extracting an abstract meaning from the reality - and image - which reproduces

* Oana DAU-GASPAR is a PhD Candidate at the Doctoral School of Sciences of Education, University of Bucharest. E-mail: oanaodg@yahoo.com 
the reality in detail. In his view, social representations have always two sides: that of image and that of meaning; they match a certain meaning to every image and a certain image to every meaning.

Given the fact that the ontogenetic stage on which we focused on in the current study is the little pupil, we analyze the social representation about the school environment as a sphere of social activity in which the child continues the development begun in the family. Under the influence of the rigors and rules of school life and its requirements, there is an essential change going on at the level of all psychological activities; the particularity of the child's thinking extends from contemplation and intuitive understanding of the phenomenon or of the case to the logic of the rule, to the law expressed by the case or the phenomenon and to operation within this conception. This fact represents a real revolution of the act of knowledge, a change of the understanding structure. Also, there takes place a change in the needs, interests, preferences of the children. There is a process of synchronizing the interests with the skills, the latter becoming more valuable for the child, who realizes the importance of the results of his activity within the school competitions (Schiopu, Verza, 1997).

Social interactions inevitably leave their mark upon the way of thinking and acting of the child. The child's behavior is modeled within the family group as well as it is shaped in time within other secondary reference groups, which thus becomes complementary to the primary family system (Golu, 1974; Neculau, 1996). If the child's interaction with the social environment in which he or she operates and completes his or her development violates certain social rules, the child will develop a deviant behavior that might eventually lead to a behavior disorder. The notion of behavior disorder suggests a slope of infant mental pathology, consisting of misfit and socially disapproved conduct, which differs by its limits from other manifestations to which the concept of mental disorder cannot be applied (Parot, Dordon, 1999). Under these considerations, the child's isolated antisocial acts should not be diagnosed as a behavior disorder, unless there are specific causes that produce them.

Knowing the causes of behavior disorders is absolutely necessary for correct diagnosis of the child and appropriate rehabilitation measures. In establishing the causes of behavior disorders there is a multitude of factors to be considered - such as genetic, organic or psychological ones (Schiopu, 1997). The genetic causes affect the anatomical constitution and IQ of the child, while organic causes include infections, poisonings and injuries (meningitis, encephalitis, infant encephalopathy, head trauma). The psychological factors may be personal or environmental. The personal or internal psychological factors concern the child's specific psychological structure and his or her superior nervous activity type. Deviations of conduct appear also due to poor intellectual capabilities, often below average or even at the lower limit of normality, and to the low interest in intellectual values (Dragomirescu, 1986). It was also noted that choleric and melancholic temperament favors up to a higher extent the behavior disorders compared to sanguinic or phlegmatic temperament. The environmental psychological factors that exert their influences from outside the individual mostly refer to social groups, like family, 
school etc., among which the child's personality develops all its aspects, including the behavioral one (Cosmovici, Iacob, 1999).

Specific behavior disorders occur at school age, such as character instability, laziness, lying, skipping classes, propriety destruction, bullying, vagrancy, negativity, theft, school drop-out, aggressive behavior, drug addiction and alcoholism, aberrant sexual behavior (Lảzảrescu, 1998).

Given the fact that the social representations are forms of practical knowledge of reality, holding both the role of symbols of the object and the role of its interpretation (Neculau, 1997), we considered the idea of comparing the social representation about school of children with behavior disorders and of those without such disorders. In this context, we started from the assumption that, because they are built during social interaction, social representations about school of the two groups of pupils will contain ideas, concepts, motives and emotional expressions that will reflect the peculiarities of their interaction with the school environment. Thus, knowledge of students' social representation about school may explain certain behaviors, but also could generate some strategies for action supporting a better integration of students with behavior disorders in the school environment.

Serge Moscovici (1997) points out the dynamic character of social representations, as they are in a perpetual movement and interaction, combining, recombining and rejecting one another; some disappear and others appear in their place. This opens the possibility for active involvement of teachers in the social representation's structure about school in order to modify the bench-marks that children with behavior disorders use to regulate their conduct and, thus, help to reduce deviant behaviors.

\section{Objectives}

Starting from the idea that the social representation about a concept has a role in regulating the behavior and attitudes toward that specific object, phenomenon or person, the present study is aimed to identify and compare the social representations about school that are formed by small pupils with and without behavior disorders. Reaching this goal may provide new directions for analysis and specific psychopedagogical approaches of students with behavior disorders.

\section{Sample}

The sample that has been studied was composed of two equal groups, totalizing 92 subjects, aged between 7 and 10 years, pupils from various primary schools in Lugoj and Timişoara. The distribution of subjects into groups was guided by the presence or absence of behavior disorders. This matter was established after consulting the school psychopedagogical records and the conclusions of psycho-behavioral assessment of children provided by 
the school psychologists - the diagnosis was made following the case history, observation and investigation conducted by the school psychologist, taking into account the indicators from ICD-10 / DSM IV (behaviors have a relatively high frequency in the last 6 months). The cases of children with sporadic deviant behavior were excluded from the analysis.

Behavior disorders of pupils that have been diagnosed with such disorders are specific to their age: physical and/or verbal aggressive behaviors, bullying or intimidating behaviors towards classmates, cruelty to animals, theft from classmates and/or from home, behaviors directed towards destroying the property of others, hyperactivity accompanied by frequent violations of the rules. The number and proportion of students who show one behavior disorder or another are found in table 1. Each child from these categories of behavior disorders is integrated in a program of individual counseling (conducted by the school counselor) and some of them also present emotional disorders - like oscillations of affective states, high levels of anxiety etc.

Table. 1. Type and percentage of each behavior disorder within the sample.

\begin{tabular}{|l|l|l|}
\hline $\begin{array}{l}\text { TYPE OF BEHAVIOR } \\
\text { DISORDER }\end{array}$ & $\begin{array}{l}\text { NUMBER OF } \\
\text { PUPILS THAT } \\
\text { MANIFEST IT }\end{array}$ & $\begin{array}{l}\text { PERCENT OF } \\
\text { PUPILS THAT } \\
\text { MANIFEST IT }\end{array}$ \\
\hline $\begin{array}{l}\text { physical and/or verbal } \\
\text { aggressive behaviours }\end{array}$ & 10 & $21,74 \%$ \\
\hline $\begin{array}{l}\text { bullying or intimidating } \\
\text { behaviors towards } \\
\text { classmates }\end{array}$ & 8 & $17,39 \%$ \\
\hline $\begin{array}{l}\text { cruelty to animals } \\
\text { theft from classmates } \\
\text { and/or from home }\end{array}$ & 5 & $10,87 \%$ \\
\hline $\begin{array}{l}\text { behaviors directed } \\
\text { towards destroying the } \\
\text { property of others }\end{array}$ & 9 & $13,04 \%$ \\
\hline $\begin{array}{l}\text { hyperactivity } \\
\text { accompanied by frequent } \\
\text { violations of the rules }\end{array}$ & 8 & $19,57 \%$ \\
\hline TOTAL & 46 & $17,39 \%$ \\
\hline
\end{tabular}




\section{Method and procedure}

The present research has a non-experimental design, in which the independent variable is the presence or absence of behavior disorders and the dependent variable is represented by the social representation about school.

The method of investigation used is the free association. In psychology, the term association is used with a double meaning: on one hand, it reflects the link established by the subjects between psychological elements - ideas, images etc. - and on the other hand, it refers to the word, idea, image that has been associated with a certain stimulus. Initially, the association was interpreted as a way that could explain the functioning of mental life. Subsequently, the epistemic "insufficiency" of this mechanism faced with the complexity of mental phenomena was proved, which led to the transformation of the association, from theory to method of exploring the human psychic. Social psychology has adopted this method in order to investigate the numerous psychosocial phenomena covered by its field. One of the social psychology areas of research that has given great importance to methods based on free association was the one focused on social representations. Most research on this theme use the association as a research method.

For this reason, in order to identify the elements of the social representations there has been used a verbal type of free association, using the induction word "school". The task given to the subjects was to indicate the first five words that come to their mind when they hear the induction term. The investigation method was applied individually, as a game in which no answer was wrong.

The raw data obtained from associative means generally have a high degree of variety and the present study is no exception to this rule. Thus, in the first phase of data processing all the words and expressions with the same or a similar meaning, associated with the stimulus, were grouped into categories of meaning. From these were then extracted the associated contents that had the highest frequencies among both groups in order to reveal the central elements of the social representations in question.

Accordingly, from all the categories of meaning identified in the association test, were extracted the words and expressions that had a frequency equal or higher than $30 \%$ among the group of subjects that produced them. The remaining words and expressions had a very large variety - they couldn't be incorporated into the categories of meaning - and a low frequency, which is why they were excluded from statistical processing.

\section{Results}

In table 2 are presented the results of the statistical processing of the data collected from the free association test responses of the subjects from both 
groups. These data are used to graphically illustrate the social representations about the school of the two groups of pupils (see figures 1,2).

In table 3 are presented the results of the pupils with behavior disorders, detailed by the type of the disorder.

Table. 2. Comparison between the categories of meaning collected at the free association test from the two groups of subjects.

\begin{tabular}{|c|c|c|c|c|}
\hline \multirow{2}{*}{$\begin{array}{l}\text { Words, expressions } \\
\text { and categories of } \\
\text { meaning }\end{array}$} & \multicolumn{2}{|c|}{$\begin{array}{l}\text { PUPILS WITH } \\
\text { BEHAVIOR } \\
\text { DISORDERS }\end{array}$} & \multicolumn{2}{|c|}{$\begin{array}{l}\text { PUPILS } \\
\text { WITHOUT } \\
\text { BEHAVIOR } \\
\text { DISORDERS } \\
\end{array}$} \\
\hline & Percent & $\begin{array}{l}\text { No. of } \\
\text { subjects } \\
\end{array}$ & Percent & $\begin{array}{l}\text { No. of } \\
\text { subjects }\end{array}$ \\
\hline TIREDNESS & $63,04 \%$ & 29 & & \\
\hline SUBJECT MATTERS & $56,52 \%$ & 26 & $41,30 \%$ & 19 \\
\hline BOREDOM & $52,17 \%$ & 24 & & \\
\hline CLASS & $47,83 \%$ & 22 & & \\
\hline DIFFICULTIES & $41,30 \%$ & 19 & & \\
\hline HELP, SUPPORT & $36,96 \%$ & 17 & & \\
\hline UGLY & $32,61 \%$ & 15 & & \\
\hline $\begin{array}{l}\text { (THE PROGRAM) } \\
\text { MILK AND BREAD } \\
\text { ROLL }\end{array}$ & $30,43 \%$ & 14 & & \\
\hline $\begin{array}{l}\text { TESTS, CONTROL } \\
\text { PAPERS }\end{array}$ & $30,43 \%$ & 14 & & \\
\hline Total & & 46 & & \\
\hline WRITING SUPPLIES & & & $54,34 \%$ & 25 \\
\hline $\begin{array}{l}\text { STUDY, } \\
\text { EDUCATION }\end{array}$ & & & $54,34 \%$ & 25 \\
\hline CLASSMATES & & & $50 \%$ & 23 \\
\hline TEACHER & & & $45,65 \%$ & 21 \\
\hline BEAUTIFUL & & & $36,96 \%$ & 17 \\
\hline CLEAN & & & $36,96 \%$ & 17 \\
\hline PLAY & & & $34,78 \%$ & 16 \\
\hline $\begin{array}{l}\text { HOMEWORK, } \\
\text { LESSONS } \\
\end{array}$ & & & $30,43 \%$ & 14 \\
\hline Total & & & & 46 \\
\hline
\end{tabular}


Table. 3. The results collected at the free association test from the group of pupils with behavior disorders, detailed by the type of the disorder.

\begin{tabular}{|c|c|c|c|c|c|c|c|c|c|c|c|c|}
\hline \multirow{3}{*}{$\begin{array}{l}\text { Words, } \\
\text { expressions } \\
\text { and } \\
\text { categories of } \\
\text { meaning }\end{array}$} & \multicolumn{12}{|c|}{ BEHAVIOR DISORDERS } \\
\hline & \multicolumn{2}{|c|}{$\begin{array}{l}\text { physical } \\
\text { and/or } \\
\text { verbal } \\
\text { aggressi } \\
\text { veness }\end{array}$} & \multicolumn{2}{|c|}{$\begin{array}{l}\text { bullying } \\
\text { or } \\
\text { intimidati } \\
\text { ng the } \\
\text { classmate } \\
\text { s }\end{array}$} & \multicolumn{2}{|c|}{$\begin{array}{l}\text { cruelty } \\
\text { to } \\
\text { animals }\end{array}$} & \multicolumn{2}{|c|}{$\begin{array}{l}\text { theft from } \\
\text { classmates } \\
\text { and/or } \\
\text { from home }\end{array}$} & \multicolumn{2}{|c|}{$\begin{array}{l}\text { destroying } \\
\text { other } \\
\text { people's } \\
\text { property }\end{array}$} & \multicolumn{2}{|c|}{$\begin{array}{l}\text { hyperactivi } \\
\text { ty, } \\
\text { frequent } \\
\text { violations } \\
\text { of the rules }\end{array}$} \\
\hline & $\mathbf{N}$ & $\%$ & $\mathrm{~N}$ & $\%$ & $\mathbf{N}$ & $\%$ & $N$ & $\%$ & $\mathbf{N}$ & $\%$ & $\mathbf{N}$ & $\%$ \\
\hline TIREDNESS & 6 & $60 \%$ & 5 & $62.5 \%$ & 3 & $60 \%$ & 2 & $33,3 \%$ & 6 & $66,6 \%$ & 7 & $87,5 \%$ \\
\hline $\begin{array}{l}\text { SUBJECT } \\
\text { MATTERS }\end{array}$ & 7 & $70 \%$ & 3 & 37,5 & 2 & $40 \%$ & 4 & $66,6 \%$ & 5 & $55,5 \%$ & 5 & $62,5 \%$ \\
\hline BOREDOM & 8 & $80 \%$ & 6 & $75 \%$ & 3 & $60 \%$ & 1 & $16,6 \%$ & 2 & $22,2 \%$ & 4 & $50 \%$ \\
\hline CLASS & 5 & $50 \%$ & 7 & $87,5 \%$ & 1 & $20 \%$ & 3 & $50 \%$ & 3 & $33,3 \%$ & 3 & $37,5 \%$ \\
\hline $\begin{array}{l}\text { DIFFICULT } \\
\text { IES }\end{array}$ & 6 & $60 \%$ & 4 & $50 \%$ & 2 & $40 \%$ & 1 & $16,6 \%$ & 0 & $0 \%$ & 6 & $75 \%$ \\
\hline $\begin{array}{l}\text { HELP, } \\
\text { SUPPORT }\end{array}$ & 2 & $20 \%$ & 1 & $12,5 \%$ & 2 & $40 \%$ & 2 & $33,3 \%$ & 4 & $44,4 \%$ & 6 & $75 \%$ \\
\hline UGLY & 7 & $70 \%$ & 1 & $12,5 \%$ & 3 & $60 \%$ & 1 & $16,6 \%$ & 1 & $11.1 \%$ & 2 & $25 \%$ \\
\hline $\begin{array}{l}\text { (THE } \\
\text { PROGRAM) } \\
\text { MLLK AND } \\
\text { BREAD } \\
\text { ROLL }\end{array}$ & 3 & $30 \%$ & 2 & $25 \%$ & 1 & $20 \%$ & 4 & $66,6 \%$ & 2 & $22,2 \%$ & $\frac{7}{2}$ & $25 \%$ \\
\hline $\begin{array}{l}\text { TESTS, } \\
\text { CONTROL } \\
\text { PAPERS }\end{array}$ & 4 & $40 \%$ & 1 & $12,5 \%$ & $\overline{1}$ & $20 \%$ & 2 & $33,3 \%$ & 2 & $22,2 \%$ & 4 & $50 \%$ \\
\hline
\end{tabular}

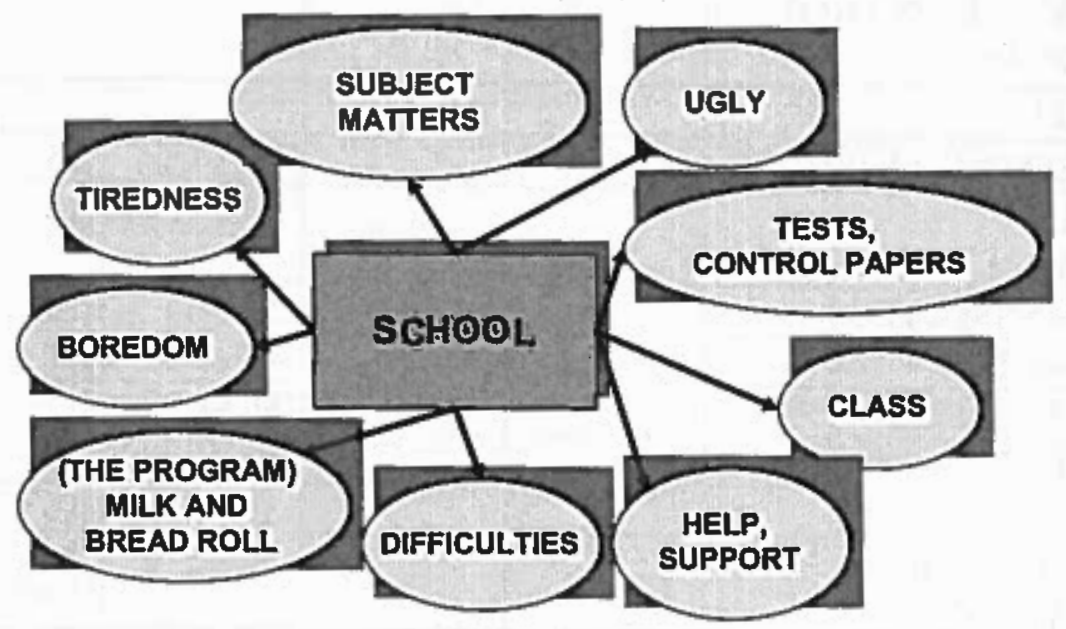

Figure 1. Social representation about SCHOOL of pupils with behavior disorders 


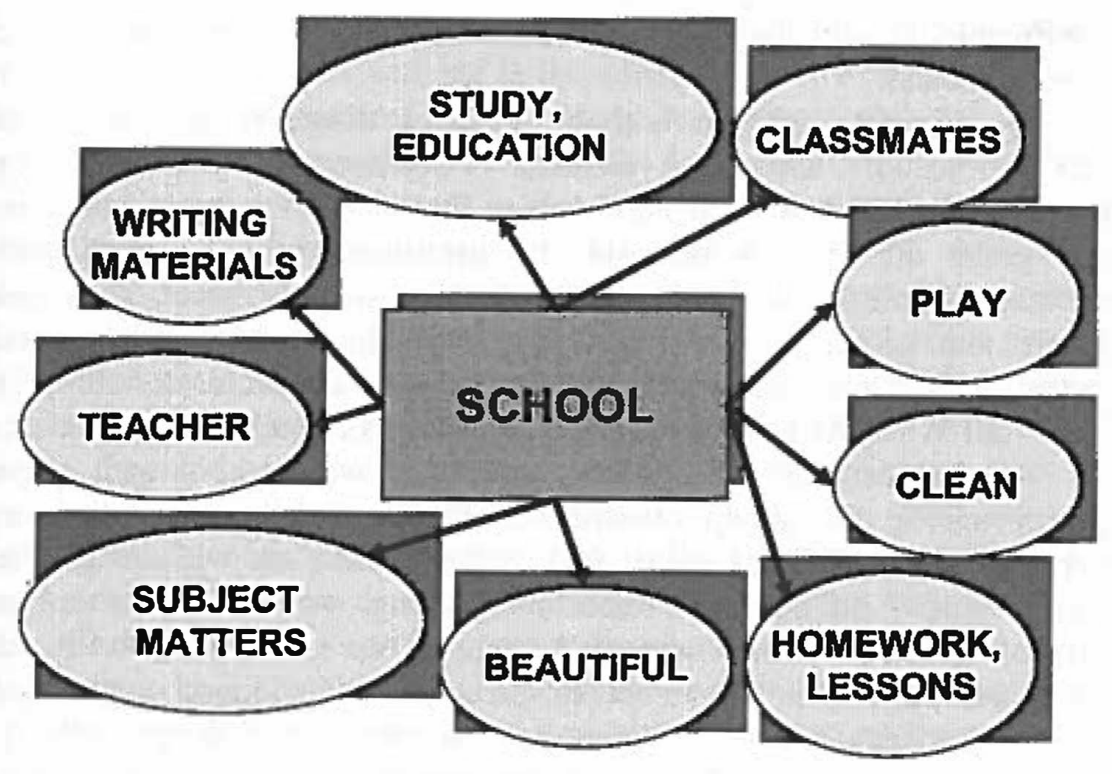

Figure 2. Social representation about SCHOOL of pupils without behavior disorders

\section{Discussion}

Comparative analysis of social representations about school of the two categories of subjects reveals major differences at the level of the central elements.

First of all it should be noted that many of the pupils with behavior disorders associate with school words like "tired", "boredom", "difficulties". For these students, school and school tasks cause fatigue and boredom because of the perceived high degree of difficulty. The perceived difficulty of school tasks may be explained by the fact that behavior disorders are often associated with an attention deficit syndrome (Lăzárescu, 1998). Failure in maintaining a focused attention for a longer period of time of these subjects leads in most cases to consider school tasks as tedious and/or boring.

Disorganization and poor coordination of activities, lack of perseverance in the activity, tendency to pass to another task before the completion of the previous are issues that often accompany the behavior disorders, thus resulting in the inability of children with these disorders to adapt to the demands of the teacher made during classroom activity. In consequence, the teacher's activity must be carefully planned from the beginning of the school year in such a way that the pupils' tasks and obligations comply with 
their individual possibilities and the measure in which they are able to structure their work in class.

By contrast, children without behavior disorders associate positive aspects to "school". One such element is represented by the category of meaning "study, education", which leads to the conclusion that subjects in this second group are able to perceive the usefulness of the school and the contribution it brings to the personal development of the student. They seem to be aware that acquiring new knowledge, both theoretical and practical, is important to their subsequent development. In contrast, children with behavior disorders fail to see the role school plays in the lives of human individuals.

Another category of meaning associated with school with increased frequency among the group of children without behavior disorders is the concept of "playing". These pupils feel well at school, are well integrated into the school social environment, therefore playing, which remains a specific activity of the small school age, still occupies an important role at school. Furthermore, playing is a symbol of pleasure at childhood age, thus this association between school and play reflects the way children without any behavior disorders feel in school (it is not uncommon for these children to use the phrase "I got bored during the holiday!" along with the manifestations of impatience towards the beginning of the next school year). In opposition, children with behavior disorders feel bored and tired at school and they get overwhelmed by the difficulties of the tasks, lacking positive feelings about the school experience.

Another noteworthy aspect is that many subjects from the group with behavior disorders believe that school is "ugly". At the small school age this word is often associated by children to any matter which they consider unpleasant. Thus, we can say that this result is the expression of these children's maladjustment to the school, which creates a feeling of annoyance. This deep feeling is extrapolated to the whole concept of school, stressing the attitude of children with behavior disorders towards this institution.

In contrast, the school is seen by children without behavior disorders as "beautiful" and "clean". These two words reflect both a positive image of the school's physical characteristics and the pleasant feelings these students have towards it. They feel good at school, they enjoy school activities unlike children with behavior disorders, who find it "ugly" and unpleasant. The attitude difference between the two groups of children is therefore closely related to the manner in which each category of pupils manages to integrate within the school environment and to the extent to which they cope with school tasks: a normal child, without any conduct problems, is able to establish a balanced relationship with the school, finding the energy required by a harmonious adaptation to the teacher's solicitations; meanwhile, a child with behavior disorder is unable to develop adaptive behavioral patterns, which leaves his integration into the school environment significantly impaired. 
A proof of the seriousness with which students without behavior disorders regard the school activity is the association between the concept of school and that of educational activity, such as "homework" and "lessons". Homework and lessons monopolize a lot of the small pupil's time spent both in school and at home, which explains in fact their association with the concept of school at this age. Primary school students with no behavior disorders are usually conscientious ones, who pay special attention to preparing lessons at home and doing homework. More to ir, the higher involvement of the parents in this kind of educational activities, like the supervision of homework or checking the accuracy of it, might trigger the perception of homework as a very important activity in the mind of children without behavior disorders. On the other hand, the group of pupils with behavior disorders mainly focuses on "tests and control papers". This association refers again to the idea of difficulty of intellectual effort. Periodical classroom assessments, which take the form of control papers, have as effect upon students with behavior disorders an increased level of stress, as they prove to be in fact thresholds that they pass with great difficulty.

The teacher must keep in mind that evaluation is an important aspect of school activity and that if it is not designed according to students' individual possibilities, may lead to leaming difficulties and school failure. It is advisable that the teacher should structure and implement a differentiated evaluation for these children, with items and rating system different from the assessment system applied to children without leaming disabilities.

It is gratifying that school is associated with the idea of "help and support" by pupils with behavior disorders, this being a clue of their understanding of the role that the education institution and the teacher have upon their full education and development.

Another element associated with school is the concept of "class". On one hand, we can explain this result based on the fact that students activate in a social context when at school, meaning they activate among a class as a social group. On the other hand, another explanation that might be in fact more plausible in this case, would be that "class" is a relatively common word when talking about the school: parents, teachers and students often use it to express different ideas: "go to class", "classmates", "class lesson", "classroom", "be quiet in class" etc.

Children without behavior disorders associate with school the word "teacher". This fact is also an expression of harmonious adaptation of these subjects to the school social environment, in which the classroom teacher occupies a central role. The affection that a child is developing toward the teacher that coordinates the classroom activity significantly marks his or her attitude toward school. This fact is even more obvious if we take into consideration the ambivalent attitude toward the school manifested by the pupils with behavior disorders, who do not think of the classroom teacher as a source 
of fun and joy and did not associate this word in a bigh extent with the induction term.

The association between school and "classmates" appears in the group of pupils without behavior disorders as a continuance of the association between the school and the teacher. The mention of the classmates is a proof of adaptation to the school social environment and classroom integration. Generally, students without behavior disorders manage to establish quality social relationships at school, based on the fact that their grades at school are above average. In contrast, children with behavior disorders mention among the associations they make with the school the word "class", thus suggesting the idea of forced uniformity and formal integration in a context mainly imposed and less wanted. If classmates are a symbol of optimal social integration of children without behavior disorders, the term "class" signifies the impersonal social collectivity which lacks the affection feelings between members. For the children with behavior disorders, "the class" is more an expression taken from adults or peers than a meaningful experience of social integration.

Other aspects that the group of children with behavior disorders associates with school are "milk" and "bread rolls" that pupils receive daily as part of a social program funded by the Government. The interpretation of this result may be linked to the fact that, as statistics show, children with behavior disorders usually come from poor and dysfunctional families, with low incomes and a rather large number of members to which the available amount of food often proves to be insufficient. Under these circumstances, the modest food supplies that pupils receive at school may become relevant to their social representation about school.

The students without behavior disorders rather associate school with "writing supplies" - a global concept under which we included items such as pen, pencil, ruler, pencil cases, notebooks etc. A possible explanation for the presence of these items in the social representation about school may be found in the fact that children without behavior disorders are usually capable of better coordination of activities and are tidier compared with pupils with such disorders, thus they are more concerned about the appearance of their writing supplies and how they are organized.

The only element common to both social representations about the school of the two groups is the category of meaning "subject matters". In this category have been integrated all enumerations of the school subjects mentioned by the pupils - mathematics, reading, writing, history, geography, science. We believe this result is a consequence of the fact that the curriculum that the school education of children is operated by is divided into subjects and therefore all these topic matters are a natural extension of the idea of school. 


\section{Conclusions}

Differences in social representations about school between the students with behavior disorders and without such disorders are a solid indication that the school experience for each of these groups is different and therefore the attitude of the two categories of pupils toward school is different.

The social representation about school of the pupils without any behavior disorders contains mostly positive oriented elements, being an expression of their school success, both at cognitive and social level. A student who loves his or her teacher, who feels comfortable among the social group of classmates, who does not find homework to be difficult will end up loving school and seeing it as being "beautiful" and "clean". Furthermore, the child's devotion toward school is enhanced by the perceived usefulness of knowledge gained in the school context.

On the other hand, children with behavior disorders are disadvantaged by their inability to adapt to the cognitive and social demands of the school environment, thus their perceptions of school tasks are often associated with fatigue or boredom. They feel overwhelmed with tests and they often face difficulties. However, school can offer support to these individuals in dealing with the tension they face in the family environment or provide food to compensate for the poverty at home. All these elements contribute to a social representation characterized by an ambivalent attitude about school.

The value of the current research lays in the fact that identification of social representation about the school provides a clearer picture of how each category of subjects interpret the social interactions from the school social environment. Knowing the different meanings the school has for students with behavior disorders compared with the ones without such disorders could prove to be a very useful tactical aspect in building an effective educational and pedagogical strategy to approach each category of children. Also, the findings of this study may prove useful in choosing the counseling and psychotherapeutic approaches conducted by social workers and psychologists in order to rehabilitate the children with behavior disorders.

Equally, it is possible that focusing the education of pupils with behavior disorders both on their needs and on changing the elements of the social representation about school might contribute to the improvement of their social interaction in the school environment and to reducing their behavioral deviance. In the past, when problems arose in schools, they used to be regarded as belonging to the children. In reality the problems belong as much to the children as to the teachers and families they come from. In school teachers can manage activities in such a manner as to correct certain perceptions, to understand and to get better understood, to ensure the acquisition of knowledge 
and the structuring of certain attitudes favorable to achieving the educational objectives and to regulating the students' social behavior.

\section{REFERENCES}

1. BONCU, S. (2000). Psihologie şi societate. Iaşi: Editura Polirom.

2. COSMOVICI, A., IACOB, L. (1999). Psihologie şcolară. Iaşi: Editura Polirom.

3. CRETU, C. (1994). Succesul şi insuccesul scolar în Psihopedagogie. Iaşi: Editura Spiru Haret, p. 27-34.

4. CRETU, V. (2008). Abordarea pozitivă a copilului din grupurile defavorizate - conditie a incluziunii sociale în Neacşu, I., Negovan, I. V., Nica, M. (coord.), Copiii şi mediile socio-educationale vulnerabile. Bucureşti: Editura Universitară.

5. CURELARU, M. (1999). Reprezentările sociale: metode asociative de culegere a datelor. In Psihologia socială - buletinul laboratorului „Psihologia câmpului social", Universitatea A. I. Cuza. Iaşi: Editura Polirom, nr. 3.

6. DRAGOMIRESCU, V. (1986). Psihologia comportamentului deviant. Bucureşti: Editura Ştiinţifică.

7. DUMITRANA, M. (1991). Eşecul şcolar şi cauzele sale - determinanti ai ideii unei noi pedagogii în Tribuna învăłământului, nr. 5, p. 5-7.

8. EYSENCK, H. şi M. (1999). Descifrarea comportamentului uman. Bucureşti: Editura Teora.

9. GOLU, P. (1974). Psihologie socială. Bucureşti: Editura Didactică şi Pedagogică.

10.JUSSIM, L. (1989). Teacher expectations: self-fulfilling prophesies, perceptual biases and accuracy in Journal of personality and social psychology, nr. 57, p. 469-480.

11.LĀZÄRESCU, M. (1998). ICD-10. Clasificarea tulburărilor mentale şi de comportament - simptomatologie şi diagnostic clinic. Bucureşti: Editura All.

12.MOSCOVICI, S. (1997). Psihologia socială sau maşina de fabricat zei. Iaşi: Editura Polirom.

13.MONETTE, D., SULLIVAN, T., DEJONG, C. (1986). Applied social research - tool for the human services. New York: CBS College Publishing. 14.MONTEIL, J. M. (1997). Educafie şi formare. Iaşi: Editura Polirom.

15.MUGNY, G., DRĀGULESCU, A. (1998). Influenfa socială şi reprezentările sociale - o abordare experimentală. În Psihologia socială buletinul laboratorului "Psihologia câmpului social", Universitatea A. I. Cuza. Iaşi: Editura Polirom, nr. 2.

16.NEACŞU, I. (1990). Instruire şi învăfare. Bucureşti: Editura Ştiinţifică.

17.NECULAU, A. (coord.) (1996). Psihologie socială-aspecte contemporane. Iaşi: Editura Polirom. 
18.NECULAU, A. (coord.) (1997). Psihologia câmpului social: reprezentările sociale. Iaşi: Editura Polirom.

19.NECULAU, A. (2000). Controlul contextului şi manipularea reprezentărilor sociale. In Psihologia socială - buletinul laboratorului „Psihologia câmpului social", Universitatea A. I. Cuza. Iaşi: Editura Polirom, nr. 5.

20.PAPALIA, D., WENKOS OLDS, S. (1986). Human development. New York: McGraw Hill.

21.PAROT, F., DORON, R. (1999). Dicfionar de psihologie. Bucureşti: Editura Humanitas.

22.PĂUN, E. (1982). Socio-pedagogie şcolară. Bucureşti: Editura Didactică şi Pedagogică.

23. POPESCU, V. V. (1991). Succesul şi insuccesul şcolar - precizäri terminologice, forme de manifestare, cauze. În Revista de pedagogie, nr. 12, p. 9-12.

24.SARTORIUS, N. (1990). Sources and traditions in psychiatrical clasification. Toronto: Hogrefe and Huber.

25.ŞCHIOPU, U. (1997). Dicționar de psihologie. Bucureşti: Editura Babel.

26.ŞCHIOPU, U., VERZA, E. (1997). Psihologia vârstelor - ciclurile vię̧ii. Bucureşti: Editura Didactică şi Pedagogică. 